\title{
DIVERSIFIKASI PRODUK PENGOLAHAN IKAN PADA KELOMPOK IBU RUMAH TANGGA PENGUSAHA KARAMBA IKAN BANYU HIRANG, DESA BANGKAL, KECAMATAN CEMPAKA, KOTA BANJARBARU, KALIMANTAN SELATAN
}

\section{(FISH PROCESSING PRODUCT DIVERSIFICATION ON EMPLOYERS HOUSEWIFE GROUP KARAMBA FISH BANYU HIRANG, VILLAGE BANGKAL, DISTRICT CEMPAKA, BANJARBARU CITY, SOUTH BORNEO)}

\section{NOORYANTINI SOETIKNO, YUSPIHANA FITRIAL, DAN IIN KHUSNUL KHOTIMAH}

\author{
Dosen Prodi Teknologi Hasil Perikanan Fakultas Perikanan dan Kelautan \\ 1) Universitas Lambung Mangkurat \\ Email: iin.khusnul.khotimah@ulm.ac.id Telp: 081347809112
}

\begin{abstract}
Fishery product diversification activities can be used to overcome problems that are often experienced by fish cage entrepreneurs. If there is an excess harvest of fresh fish or the yield is forced to do due to sudden changes in water conditions (such as water pollution, excess capacity of the buyer, the death of fresh fish), the problem has not resolved so far. The purpose of this activity is to provide knowledge and skills for housewife of "karamba" businesspeople in the form of making presto of soft thorn carp and nugget of tilapia in Bangkal Village, Cempaka District, Banjarbaru City, South of Kalimantan. The method used in this activity is the survey, demonstration, and evaluation of the implementation of activities. The results of this activity were in the form of nuggets of tilapia and presto of soft thorn carp produced by housewives of businesspeople from Banyu Hirang Village in Bangkal Village as participants. In addition to its delicious taste, has a high protein nutritional value, these processed products can also sell as a source of household income.
\end{abstract}

Keywords: Diversification, presto of carp, tilapia nuggets, Bangkal Village

\section{Abstrak}

Kegiatan diversifikasi dapat digunakan untuk mengatasi permasalahan yang sering dialami bagi pengusaaha keramba ikan. Bila terjadi kelebihan panen ikan segar dari usaha keramba, atau panen terpaksa dilakukan akibat perubahan kondisi perairan yang mendadak (seperti pencemaran air, kelebihan daya tampung pembeli, kematian ikan namun masih segar), menjadi permasalahan yang selama ini belum teratasi. Tujuan dari kegiatan ini adalah memberikan pengetahuan dan keterampilan bagi ibu-ibu pengusahan karamba berupa pembuatan presto ikan mas duri lunak dan naget ikan nila di Desa Bangkal Kecamatan Cempaka Banjarbaru Kota Kalimantan Selatan. Metode yang digunakan dalam kegiatan ini survei, demonstrasi dan evaluasi pelaksanaan kegiatan. Hasil dari kegiatan ini berupa produk naget ikan nila dan presto ikan mas duri lunak yang di hasilkan oleh ibu-ibu rumah tangga pengusaha keramba Banyu Hirang Desa Bangkal sebagai peserta pengabdian, sehingga dapat memenuhi keinginan peserta sebagai bahan jadi yang dapat digunakan sebagai makanan enak dan bermutu/bergizi baik. Kedua produk makanan bahan jadi tersebut dapat juga dijadikan sebagai produk yang dapat dipasarkan.

Kata kunci : Diversifikasi, presto ikan mas, naget ikan nila, Desa Bangkal 


\section{BAB I. PENDAHULUAN}

\section{A. Analisis Situasi}

Kegiatan IbM teknologi diversifikasi produk pengolahan ikan diterapkan pada kelompok ibu-ibu pengusaha keramba ikan Banyu Hirang Desa Bangkal Kecamatan Cempaka Banjarbaru Kota Kalimantan Selatan. Umumnya kegiatan usaha keramba ikan telah berhasil dengan baik, sebagai produk utama usaha keramba ini adalah ikan nila dan ikan mas segar. Pemanfaatan produksi ikan hidup segar tersebut adalah menjualnya kepada pedagang perantara daan konsumen yang membeli langsung di lokasi usaha keramba. Para pedagang perantara biasanya menjual ikan hidup segar tersebut ke pasar di Kota Banjarbaru dan Martapura.

Cara Kegiatan usaha tersebut dimulai dari pengadaan bahan dan pembuatan sendiri keramba yang umumnya dibuat dari bahan kayu ulin, dengan bentuk kotak keranjang besar. Sebuah unit keramba umumnya berukuran sekitar $2 \mathrm{~m}$ (tinggi) $\times 2 \mathrm{~m}$ (lebar) $x 4 \mathrm{~m}$ (panjang) dengan volume (isi) sebesar $16 \mathrm{~m}^{3}$. Setiap unit ditempatkan/dimasukkan ke sungai yang disebut Sungai Bayu Hirang, dibantu dengan pelampung dari bahan beberapa batangan bambu dan beberapa buah bekas drum minyak, sehingga bagian keramba yang terendam dalam air sungai sekitar 1,8m dan sekitar setinggi $20 \mathrm{~cm}$ berada di permukaai air. Setiap keluarga mengelola/mengusahakan sekitar 5-10 unit keramba. Setap keramba diisi dengan bibit ikan nila atau ikan mas berukuran panjang 3-4 cm. Ikan yang telah dipelihara dalam keramba tersebut diberi pakan ikan buatan sebanyak $2 \mathrm{x}$ sehari. Pakan ikan buatan biasanya dibeli dari pasar Martapura. Pemeliharaan ikan berlangsung sekitar 6 bulan. Panen biasanya dilakukan pada saat pedagang pegumpul atau konsumen lokal akan segera membelinya. Keuntungan dari usaha keramba tersebut cukup baik untuk membiayai kehidupan keluarga seharihari.

\section{B. Permasalan Mitra}

Berdasarkan pengamatan tim pelaksana kegiatan, permasalahan yang dihadapi mitra adalah terbatasnya pemanfaatan hasil usaha utama mereka tersebut yang umumnya hanya dijual langsung kepada pedagang pengumpul dan konsumen lokal. Pada keadaan yang tidak terduga, misalnya keadaan panen yang melimpah (panen yang dilakukan bersamaan bagi beberapa pengusaha keramba) sehingga melebihi kemampuan pedagang pengumpul membelinya. Dari itu ada sisa panen yang tidak terjual, sehingga terpaksa dimasukkan kembali ke dalam keramba, dipelihara dan memerlukan pakan lagi yang akan menjadi beban bagi pengusaha. Permasalan lain yang dihadapi adalah perubahan kualitas air yang mendadak (akibat pencemaran yang tidak diketahui sebelumnya), atau munculnya dan penyebaran penyakit ikan yang cepat mengganggu kehidupan ikan.

Problem pada kehidupan ikan dalam keramba akibat kualitas air dan penyebaran penyakit tersebut, maka panen mesti segera dilakukan lebih awal. Problem tersebut biasanya tanpa penyiapan alternatif teknologi pengolahan dan pengawetan ikan yang memadai sehingga menyebabkan kematian ikan. Selanjutnya bila kekurangan fasilitas pengolahan ikan disertai keterlambatan penanganan, maka akan terjadi proses pembusukan ikan.

C. Solusi yang Ditawarkan

Tim pelaksana kegiatan mengusulkan atau menawarkan Teknologi Diversifikasi Produk Pengolahan Ikan 
berupa pemberian pengetahuan dan keterampilan bagi pengusaha keramba, dalam hal ini disampaikan khususnya bagi ibu-ibu pengusaha keramba untuk mengatasi permasalahan yang dihadapi. Penyampaian pengetahuan dan keteramplan tersebut berupa pembuatan naget daging ikan nila dan presto lunak duri ikan mas. Produk dari pengolahan ikan ini selanjutnya dapat dihidangkan atau dikonsumsi langsung bersama-sama dan sebagian lagi disimpan khusus pada kondisi dingin atau beku dalam freezer. Bahan yang disimpan sementara atau jangka waktu yang cukup lama, selanjutnya dapat dimasak utuk dinikmati selanjutnya atau dijadikan penjualan bahan masak jadi.

Usaha demikian dapat diterapkan/dikerjakan untuk banyak ikan yang mengalami permasalahan pemanenan lebih awal secara keseluruhan seperti disebutkan terdahulu. Kepada mitra juga dapaat memanfaatkan keterampilan pengolahan naget ikan dan presto ikan ini sebagai divesifikasi produk pengolahan hasil usaha keramba ikan, menjadi poduk jadi yang dapat dimanfaatkan sebagai produk ikan masak jadi pada saat-sat memungkinkan atau menambah usaha lain berupa penjualan ikan masak jadi disamping penjualan ikan segar yang biasa dilakukan.

\section{BAB II. TARGET DAN LUARAN}

Target dari kegiatan ini adalh terlaksana penyampaian pengetahuan teknoloi diversifikasi pengolahan ikan berupa pengolahan naget ikan nila dan presto coocker ikan mas, yang menggunakan bahan baku utama berupa ikan segar dari hasil usaha keramba ikan.

Luaran yang akan dihasilkan dari program ini khususnya bagi pihak mitra (kelompok ibu-ibu pengusaha keramba ikan di Desa Bangkal), yaitu :

1. Perolehan pengalaman dan keterampilan praktek teknologi pengolahan kuliner naget ikan dan presto ikan, yang dapat meragamkan atau diversifikasi dari produk utama hasil usaha keramba.

2. Dapat digunakan sebagai alternatif pemanfaatan, sehingga mencegah kerugian usaha keramba akibat terpaksa panaen awal yang tidak dapat tampung pembelinya, atau kemungkinan akibat kegagalan panen akibat perubahan kualitas perairan, sebaran penyakit, atau akibat lainnya yang terduka sebelumnya.

Bagi tim kegiatan pengabdian kepada masyarakat kegiatan ini merupkn wujud peningkatn atensi akademisiterhadap masyarakat. Hal ini membuka peluang dan kesempatan bgi para pengabdi untuk mengamalkan ilmu pengetahuan bagi kepentingan masyarakat sebagai bentuk nyata dari Tri Dharma Perguruan Tinggi yng berupa Pengabdian Kepada Masyarakat

\section{BAB III. METODE PELAKSANAAN}

Metode proses pelaksanaan pengabdian kepada masyarakat ini direncanakan akan meliputi tahapan sebagai berikut:

1. Kunjungan awal untuk mengetahui domisili dari kelompok usaha keramba ikan, dan membuat penyampaian ide untuk mengadakan pengabdian berupa penyuluhan pemanfaatan dari hasil usah keramba ikan sehingga menjamin kelancaran dan keberhasilan usaha tersebut jangka panjang, sekaligus mengatasi atau mencegah terjadinya kegagalan usaha. 
2. Penyusunan proposal formal (TOR) sebagai salah satu kegiatan dari LPM Universitas Lambung Mangkurat, sehingga memperoleh penyediaan dana bagi pembiayaan pengabdian tersebut.

3. Kunjungan kedua kepada kelompok usaha keraba ikan dengan maksud mengadakan pertemuan dan diskusi dengan kelompok ibu-ibu pengusaka keramba ikan tersebut. Tujuan utama adalah penjelasan masud penerapan teknologi pengolahan hasil perikanan dengan maksud untuk menjain keberhasilan (mencegah kegagalan panen) usaha keramba mereka disamping dapat menikmati dan memanfaatkan diversifikasi produk pengolahan naget daging ikan nila dan presto lunak duri ikan mas. Tujuan selanjutnya dari kunjungan ke dua kali ini adalah mendiskusikan persiapan waktu, tempt dan identifikasi/perkiraan berbagai bahan dan peralatan yang diperlukan. Sebagian besar peralatan akan disiapkan dan dibawa ke lokassi oleh tim pelaksana pengabdian, beberapa bahan dipersiapkan oleh mitra (ibu-ibu kelompok usaha keramba ikan).

4. Kunjungan ketiga adalah pelaksanaan pengabdian, berupa penjelasan mengenai pengolahan naget daging ikan nila, praktek keterampilan pengolahan/pemasakan kuliner naget ikan, sampai dihasilkan produk naget daging ikan yang dapat dinikmati. Disamping itu juga disiapkn naget yang disimpan sehingga dapat menikmati pada waktu lain akan datang bagi keluarga masing-msing peserta.

5. Kunjungan ke empat adalah pelaksanaan pengabdian, berupa penjelasan mengenai pengolahan presto lunak duri ikan mas, praktek keterampilan pengolahan/pemassakan kuliner presto ikan mas, sehingga dihasilkan produk presto ikan mas yang dapat dinikmati.
Disamping itu juga disiapkan produk presto ikan mas yang disimpan untuk dapat dinikmati pada waktu lin yang akan datang bagi keluarga masing-masing peserta.

6. Kunjungan ke lima adalah semacam monitor pelaksanaan pemanfaatan teknologi pengolahan/pemasakan kuliner naget daging ikan nil dan presto ikan mas tersebut pada keluarga peserta mitra pengabdian. Dilaksanakan diskusi sekaligus kami menerima komentar mengenai penerapan teknologi pengolahan ikan dari peserta mitra pengabdian, selanjutnya akan digunakan sebagai bahan penyusunan laporan.

Pada setiap kunjungan akan diikuti oleh anggota tim pelaksana disertai 2 orang dosen dan dibantu 4-5 orang mahasiswa serta peserta dari ibu-ibu kelompok usaha keramba ikan sebagai mitra, diharapkan diikuti 10-15 ibu-ibu pengusaha keramb ikan di Desa Bangkal ini.

Selain tim pelaksana (pengusul) dan mitra, ada berbagai pihak yang juga terkait dan mendukung terhadap kegiatan ini, yaitu : Dikti, LPM Unlm, Tim Pengusul (Pelaksana), peserta sasaran (mitra), dan pimpinan Lembaga Desa. Peran dari pihak-pihak tersebut sebagai berikut:

\section{BAB 4. HASIL PELAKSANAAN PENGABDIAN}

Kegiatan diversifikasi produk pengolahan ikan ini dilaksanakn pada kelompok ibu-ibu pengusaha keramba ikan Banyu Hirang di Desa Bangkal, Kecamatan Cempaka, Banjarbar Kota, Kalimantan Selatan. Peserta kegiatan ini diikuti ibu-ibu sebanyak 15 orang dengan usia berkisar antara 25-40 tahun. Ibu-ibu peserta kegiatan merasa sangat beruntung memperoleh pengetahuan tentang pengolahan pesto ikan nila dan naget ikan mas, karena selama ini hasil panen keramba yang tidak terjual 
(khususnnya ikan yang mati) dibagikan kepada tetangga sekitar rumah tinggal mereka. Sehingga dengan adanya demonstrasi pada kegiatan ini ikan mas dan ikan nila yang menjadi hasil utama usaha keramba dapat dimanfaatkan secara optimal.

Hasil evaluasi awal menunjukkan bahwa hanya sekitar $60 \%$ peserta kegiatan yang baru mengetahui tentang produk olahan presto dan naget ikan tersebut. Umumnya para peserta mengetahui tentang produk tersebut dari iklan televisi, tetapi mereka belum pernah mencoba mengolah sendiri daging ikan menjadi naget dan presto ikan. Hasil evaluasi akhir menunjukkan bahwa 93\% peserta kegiatan ini telah dapat atau mampu mengerjakan pembuatan presto ikan mas dan pengolahan naget ikan nila.

\section{A. TEKNOLOGI YANG DITERAPKAN}

1. Pengolahan Naget Ikan Nila

Tabel 1. Bahan yang Digunakan dalam Pengolahan Naget

\begin{tabular}{|l|l|l|}
\hline No. & \multicolumn{1}{|c|}{ Bahan } & \multicolumn{1}{c|}{ Kuantitas } \\
\hline 1. & $\begin{array}{l}\text { Daging ikan nila } \\
\text { segar }\end{array}$ & $20 \mathrm{~kg}$ \\
\hline 2. & Roti tawar & $10 \mathrm{bungkus}$ \\
\hline 3. & Telur ayam & $4 \mathrm{~kg}$ \\
\hline 4. & Tepung panir & $2 \mathrm{~kg}$ \\
\hline 5. & Minyak goreng & $5 \mathrm{liter}$ \\
\hline 6. & Garam & $500 \mathrm{~g}$ \\
\hline 7. & Pala & $20 \mathrm{biji}$ \\
\hline 8. & Thyme & $500 \mathrm{~g}$ \\
\hline
\end{tabular}

Tabel 2. Peralatan yang Digunakan dalam Pengolahan Naget

\begin{tabular}{|l|l|l|}
\hline No. & Nama Alat & \multicolumn{1}{|c|}{ Fungsi } \\
\hline 1. & Blender & $\begin{array}{l}\text { Untuk } \\
\text { menghaluskan } \\
\text { bumbu }\end{array}$ \\
\hline 2. & Baskom & $\begin{array}{l}\text { Untuk menguleni } \\
\text { adonan }\end{array}$ \\
\hline
\end{tabular}

\begin{tabular}{|l|l|l|}
\hline 3. & Kompor & Untuk memasak \\
\hline 4. & $\begin{array}{l}\text { Panci } \\
\text { Kukusan }\end{array}$ & $\begin{array}{l}\text { Untuk mengukus } \\
\text { adonan naget ikan } \\
\text { nila }\end{array}$ \\
\hline 5. & Wajan & $\begin{array}{l}\text { Untuk menggoreng } \\
\text { naget ikan nila }\end{array}$ \\
\hline 6. & Piring & $\begin{array}{l}\text { Tempat } \\
\text { menghidangkan } \\
\text { naget ikan nila }\end{array}$ \\
\hline
\end{tabular}

2. Prosedur Pengolahan Naget Ikan Nila

1. Ikan disiangi, dibersihkan, gunakan hanya daging ikan nila

2. Tambahkan roti tawar dan isi telur ayam

3. Blender adonan tersebut menjadi adonan naget ikan

4. Massukkan bumbu dan aduk/blender hingga rata

5. Siapkan loyang, olesi dengan minyak goreng, dan alasi dengan kertas roti

6. Masukkan/tuangkan adonan ke dalam loyang secukupnya

7. Siapkan panci, isi dengan air tawar secukupnya, dan masukkan loyang yag berisi adonan ke dalam panci tersebut dan panci ditutup

8. Siapkan kompor dan nyalakan, tempatkan panci berisi adonan tersebut di atas kompor

9. Lakukan proses pengukusan adonan naget, biarkan selama 30 menit

10. Matikan kompor, keluarkan loyang berisi adonan naget yang telah masak

11. Biarka adonan tersebut hingga dingin, potong-potonglah naget yang telah masak sesuai ukuran selera

12. Pisahkan 2 kelompok naget yang telah masak kukus tersebut, sebagian disimpan dalam kultas untuk keperluan selanjutnya 
13. Sebagian lagi disipkan untuk digoreng

14. Taburi potongan naget ikan nila dengan panir, seterusnya celup ke dalam putih telur yang disiapkan erlbih dahulu, dan taburi lagi dengan panir

15. Siapkan wajan berisi minyak goreng, tempatkan di atas kompor, dan nyalakan api kompor

16. Masukkan beberapa potong naget tersebut ke dalam minyak goreng yang telah panas

17. Proses penggorengan akan berlangsung bebeapa saat smpai potongannaget akan berwarna kecoklatan

18. Anggat naget yang telah masak dan siapkanuntuk dihidangkan

19. Selamat mencoba

3. Pengolahan Presto Ikan Mas Duri Lunak

Tabel 3. Bahan yang Digunakan dalam Pengolahan Presto Ikan Mas Duri Lunak

\begin{tabular}{|l|l|l|}
\hline No. & Bahan & Kuantitas \\
\hline 1. & $\begin{array}{l}\text { Daging ikan mas } \\
\text { segar }\end{array}$ & $20 \mathrm{~kg}$ \\
\hline 2. & Jeruk nipis & 20 biji \\
\hline 3. & Ragi tape & 20 sendok \\
\hline 4. & Serai & 80 batang \\
\hline 5. & Daun salam & 80 lembar \\
\hline 6. & Daun sereh & 80 lembar \\
\hline 7. & Lengkuas & $\begin{array}{l}20 \text { potong @ 8 } \\
\text { cm }\end{array}$ \\
\hline 8. & Daun pisang & Secukupnya \\
\hline 9. & Jahe & $\begin{array}{l}20 \text { potong @ 2 } \\
\text { cm }\end{array}$ \\
\hline 10. & Kunyit & $\begin{array}{l}20 \text { potong @ 5 } \\
\text { cm }\end{array}$ \\
\hline 11. & Bawang putih & 240 siung \\
\hline 12. & Gula pasir & 20 sendok teh \\
\hline 13. & Garam & $\begin{array}{l}45 \\
\text { makan }\end{array}$ \\
\hline 14. & Telur ayam & 20 biji \\
\hline
\end{tabular}

Keterangan : bahan no.1 bahan utama, no. 2-8 bahan pelumas, no. 9-13 sebagai bumbu, dan no.14 ditambah sedikit bahan no.13 disebut pelapis

Tabel 4. Peralatan yang Digunakan dalam Pengolahan Presto Ikan Mas Duri Lunak

\begin{tabular}{|l|l|l|}
\hline No. & \multicolumn{1}{|c|}{ Nama Alat } & \multicolumn{1}{|c|}{ Fungsi } \\
\hline 1. & Presto cooker & $\begin{array}{l}\text { Untuk melunakkan } \\
\text { duri ikan mas }\end{array}$ \\
\hline 2. & Baskom & $\begin{array}{l}\text { Untuk menguleni } \\
\text { ikan dengan } \\
\text { bumbu }\end{array}$ \\
\hline 3. & Kompor & Untuk memasak \\
\hline 4. & Refrigerator & $\begin{array}{l}\text { Untuk menyimpan } \\
\text { sementara supaya } \\
\text { bumbu meresap } \\
\text { dalam tubuh ikan }\end{array}$ \\
\hline 5. & Wajan & $\begin{array}{l}\text { Untuk menggoreng } \\
\text { presto ikan mas } \\
\text { duri lunak }\end{array}$ \\
\hline 6. & Piring & $\begin{array}{l}\text { Tempat } \\
\text { menghidangkan } \\
\text { presto ikan mas } \\
\text { duri lunak }\end{array}$ \\
\hline 7. & Pisau & $\begin{array}{l}\text { Alat untuk } \\
\text { menyiangi ikan }\end{array}$ \\
\hline
\end{tabular}

4. Proses Pengolahan Presto Ikan Mas Duri Lunak :

1. Ikan mas dikeluarkan isi perutny, dicuci, dan ditiriskan

2. Haluskan bumbu untuk melumuri tubuh daging

3. Lumuri tubuh ikan dengan air perasan jeruk nipis satu persatu

4. Berikutnya lumuri ikan dengan ragi tempe dan bumbu halus

5. Masukkan dan didiamkan dalam kulkas, untuk meresapkan bumbu pada daging tubuh ikan 
6. Isikan air tawar ke dalam presto cooker hingga setinggi saringan kukusan presto

7. Masukkan bahan berikut secara berurutan ke dalam loyang presto cooker, yaitu:

Daun pisang secukupnya pada bagian dasar loyang, diatasnya 10 lembar daun salam, 10 lembar, daun sereh, 5 potong lengkuas @ 4 cm, dan ikan mas. Terakhir, di permukaan ikan mas ditutupi dengan daun pisang

8. Presto cooker berisi ikan mas tadi diletakkan diatas kompor, dan nyalakan api kompor

9. Klep presto cooker biarkan tetap terbuka sehingga uap air berangsurangsur keluar sesuai dengan kenaikan suhu akibat pemanasan presto, ditunjukkan oleh ampere

10. Pada suhu mencapai lebih $100^{\circ} \mathrm{C}$, uap akan keluar tanpa bercampur udara lain, dan pada suhu itu tutup klep udara terbuka.

11.Suhu akan terus naik dan ampere mencapai suhu $110^{\circ} \mathrm{C}$, kecilkan api kompor sehingga kompor suhu pemasakan ikan presto stabil

12.Biarkan proses berlangsung selama 30 menit, setelah itu matikan api kompor, sehingg suhu akan turun

13. Bila suhu turun dibawah $100^{\circ} \mathrm{C}$, buka klep presto sehingga uap air keluar lagi dan suhu terus turun

14.Setelah uap air sudah tidak keluar lagi, bukalah tutup presto, bila suhu cukup rendah keluarkan loyang berisi ikan mas presto duri lunak

16.Untuk melapisi luar tubuh hasil presto ikan mas duri lunak, kocok telur ayam beri garam sedikit
17.Siapkan wajan isi dengan minyak goreng secukupnya, panaskan, masukan presto ikan mas yg sudah dicelup dalam telur ke dalam minyak panas, goreng sampai kuning keemasan, angkat dan tiriskan

18. Siapkan dalam piring saji

\section{B. PRODUK YANG DIHASILKAN}

Ikan nila yang digunakan dalm pengolhan nget sebanyak $20 \mathrm{~kg}$, kemudian dipisahkan daging dari tulang dan kulitnya, sehingga diperoleh daging bersih sebanyak $6 \mathrm{~kg}$. Daging ikan nila selanjutnya dihaluskan dengan menggunakan chopper, dicampur dengan bahan-baahn yan $\mathrm{g}$ lainnya, seterusnya dibuat adonan, dikukus hingga matang. Adonan daging ikan nila yang telah matang didinginkan, seterusnya dipotongpotong sesuai selera (bentuk seperi jari), celupkan dalam kocokan telur dan dilumuri dengan tepung panir, simpan dalam freezer. Naget ikan nila yang dihasilkan dari kegiatn ini sebanyak 480 potong.

Jenis ikan yang kedua pada kegiatan ini adalah ikan mas, yang diolah menjadi presto ikan mas. Ditimbang $20 \mathrm{~kg}$ ikan mas segar, setiap $1 \mathrm{~kg}$ ikan mas ini diperoleh 5 ekor ikan, sehingga jumlah keseluruhan adalah 100 ekor ikan mas. Kapasitas ala presure cooker yang dalam pengolahan presto dapat menampung $4 \mathrm{~kg}$ atau 20 ekor ikan mas.

Hasil produk naget ikan nila dan presto ikan mas ditampilkan pada dokumentasi kegiatn berikut ini: 


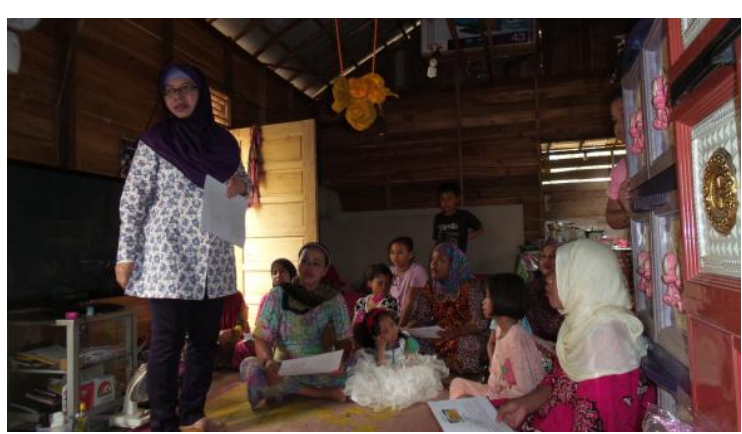

Gambar 1. Tim pengabdian memberikan penjelasan tentang pengolahan naget ikan nila dan presto ikan mas duri lunak

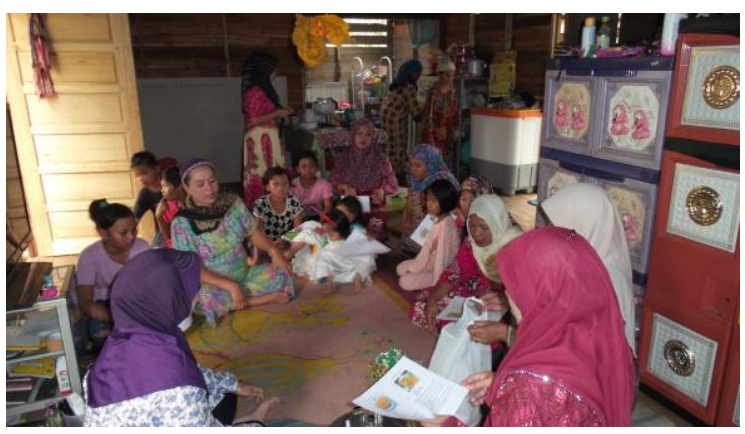

Gambar 2. Diskusi dan tanya jawab dengan peserta pengabdian

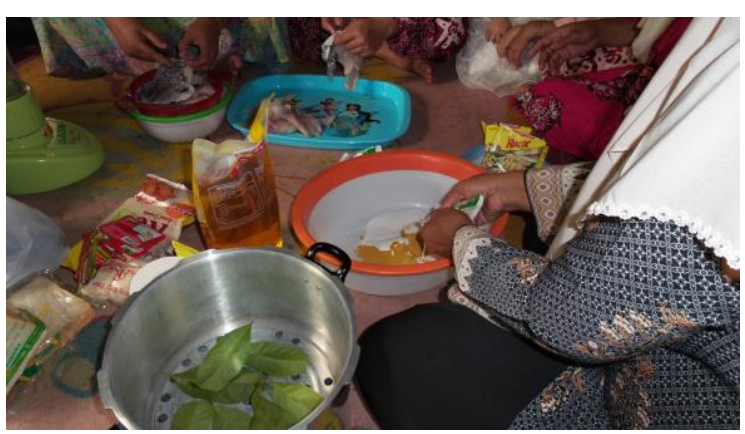

Gambar 3. Menyiapkan fillet daging ikan nila untuk naget ikan dan proses pencampuran bumbu untuk pengolahan presto ikan mas duri lunak

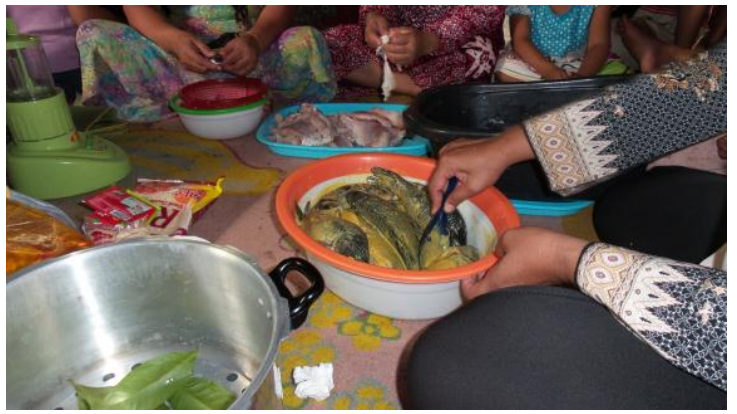

Gambr 4. Melumuri ikan mas dengan bumbu hingga merata

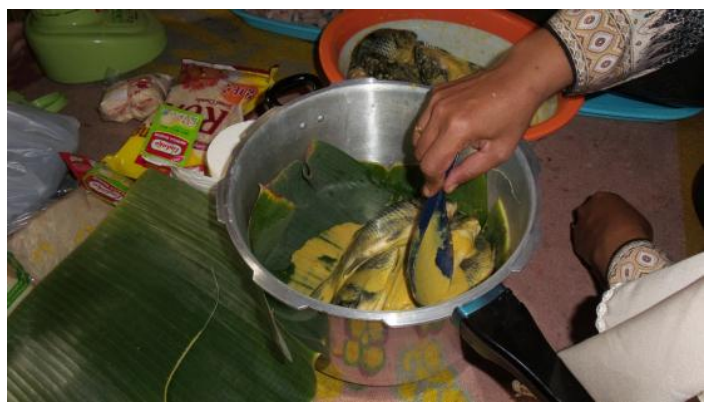

Gambar 5. Menyusun ikan mas dalm panci presto yang telah di beri alas daun pisang

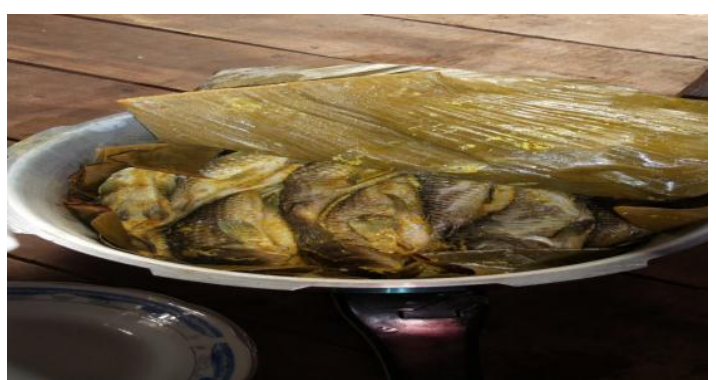

Gambar 6. Ikan mas yang telah selesai di presto

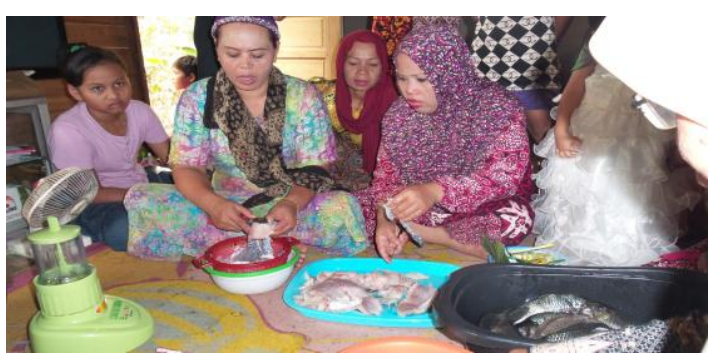

Gambar 7. Menyiapkan fillet daging ikan nila 


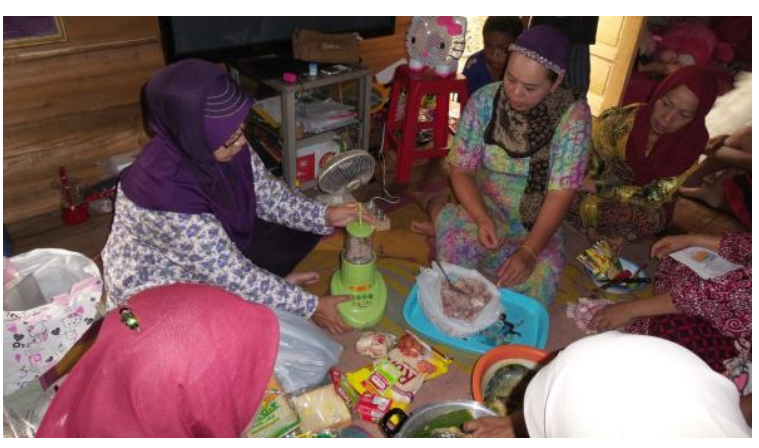

Gambar 8. Menghaluskan daging ikan nila dengan chopper

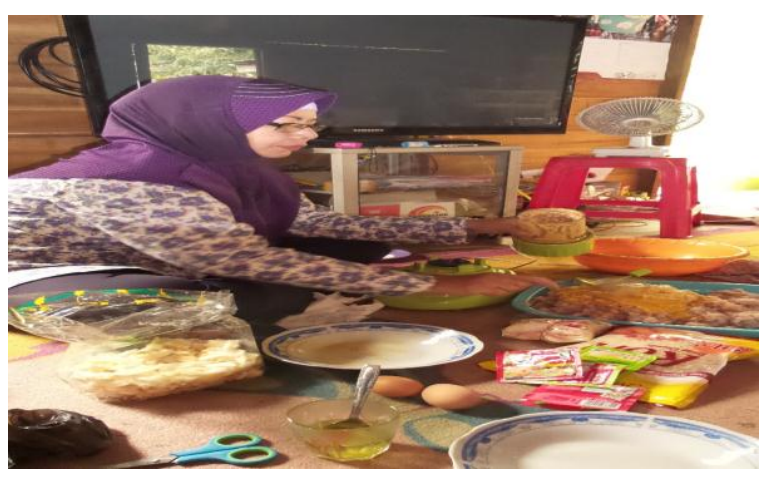

Gambar 9. Menambahkan bumbu ke adonan naget ikan nila

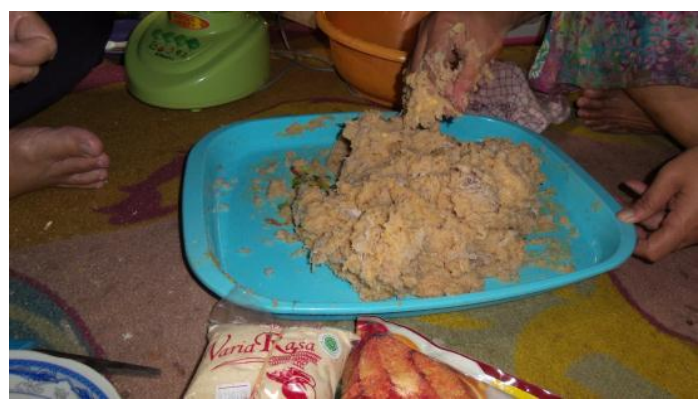

Gambar 10. Proses pencampuran daging ikan nila giling dengan bumbu naget

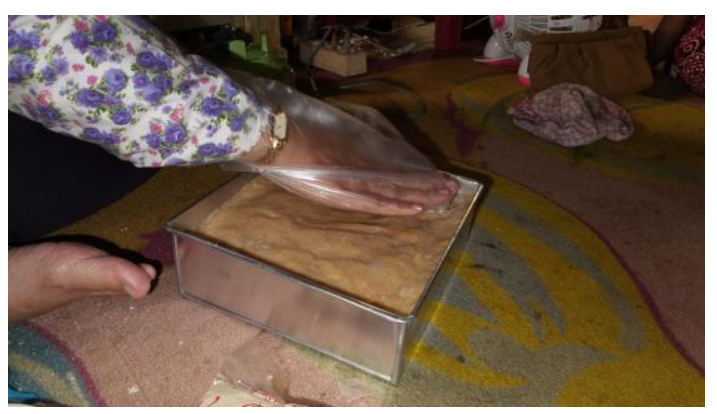

Gambar 11. Adonan naget siap dikukus

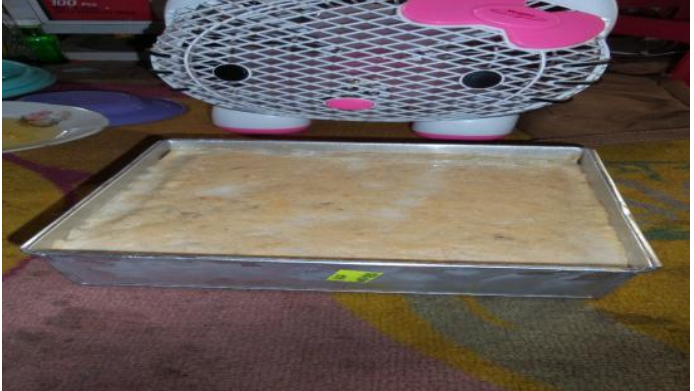

Gambar 12. Proses mendinginkan adonan naget yang telah dikukus

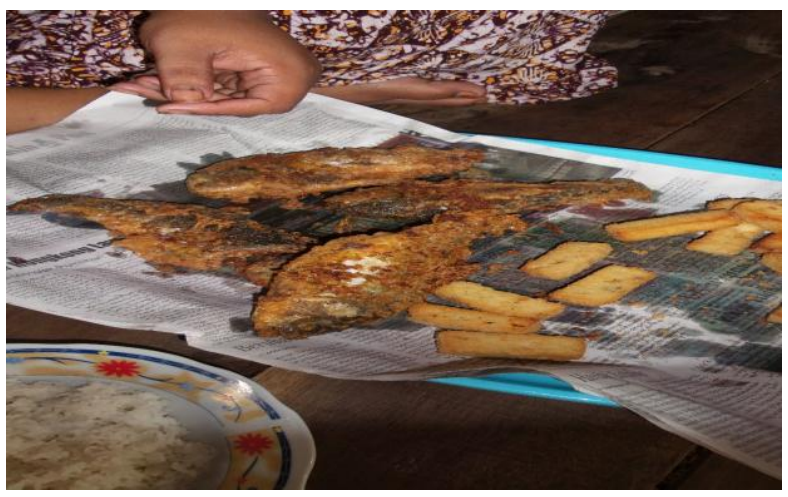

Gambar 13. Presto ikan mas duri lunak dan naget ikan nila siap dihidangkan

\section{BAB 6. KESIMPULAN DAN SARAN}

Produk berupa naget ikan nila dan presto ikan mas duri lunak yang di hasilkan oleh ibu-ibu rumah tangga pengusaha keramba Banyu Hirang Desa bangkal sebagai peserta pengabdian ini, dapat memenuhi keinginan peserta sebagai bahan jadi yang dapat digunakan sebagai makanan enak dan bermutu/bergizi baik. Kegiatan pengolahan ini dapat digunakan untuk mengatasi permasalahan yang sering dialami bagi pengusaaha keramba ikan. Bila terjadi kelebihn panen ikan segar dari usaha keramba, atau terjadi panen terpaksa dilakukan akibat perubahan kondisi perairan yang mendadak (seperti pencemaran air, atau kelebihan daya tampung pembeli, atau kematian ikan namun masih segar), menjadi permasalahan yang selama ini belum teratasi. Hasil keramba tersebut, 
selanjutnya dapat diproses menjadi produk naget dan pesto ikan yang dapat dinikmati oleh keluarga. Kedua produk makanan bahan jadi tersebut dapat juga dijadikan sebagai produk yang dapat dipasarkan.

\section{UCAPAN TERIMAKASIH}

Terimakasih disampaikan kepada Universitas Lambung Mangkurat yang telah membiayai kegiatan ini melalui DIPA-BOPTN dengan Surat Perjanjian Pelaksanaan Program (SPPP) no: 134/UN8/PM/DIPA-BOPTN/2014 tanggal 5 Agustus 2014.

Terimakasih yang setinggi-tingginya juga dihaturkah kepada Prof. Ir. H. Djasmani Hisbi, MS, MSc (alm) atas dedikasi dan totalitasnya dalam pelaksanaan kegiatan IbM di Desa Bangkal, Kecamatan Cempaka Banjarbaru Kota Kalimantan Selatan.

\section{DAFTAR PUSTAKA}

Abimanyu. 2009. Pengaruh Penyimpanan Beku terhadap Kualitas Produk Nugget lkan Laut Manyung (Arius thalassinus L.) dan Ikan Lele Air Tawar (Clarias Gariepinus B.). Laporan Skripsi Program Studi Biologi, Fakultas Teknologi, Universitas Atmajaya, Yogyakarta.

Adawyah, R. 2007. Pengolahan dan Pengawetan Ikan. Bumi Aksara. Jakarta.

Hadiwiyoto, S. $1995 . \quad$ Teknologi Pengolahan Hasil Perikanan. Liberty. Yogyakarta.

llyas. 1983. 1983. Teknologi Refrigerasi Hasil Perikanan. Teknologi
Pendinginan Ikan. CV. Paripurna. Jakarta.

Karida, N., Sunyoto, dan W. Aryadi, 2014. Uji Kualitas Bandeng Presto dengan Alat Low. Journal.Unnes.ac.id/index.php/sain teknol (diakses 27 Juni 2014).

Novia, Sri. R. 2003. Pembuatan Nugget Ikan dari Jenis Ikan yang Berbeda Terhadap Penerimaan Konsumen. Skripsi. Fakultas Perikanan. Universitas Lambung Mangkurat. Banjarbaru.

Purpasari, D. 2011. Pemberian Jenis Umbi yang berbeda sebagai Sumber Karbohidrat Alternatif untuk perbaikan Tekstur Nugget Ikan Nila. Skripsi. Fakultas Perikanan dan IImu Kelautan. Universits Lambung Mangkurat.

Salman, M.L. 1999. Nugget Udang. Instansi Teknologi Hasil Pertnian. PPG. Pertanian. Jakarta.

Susanto, E. 2010. Pengolahan Bandeng (Chanos-chanos Forsk) Duri Lunak. Seri Matei Penyulhan Bagi Masyarakat Pesisir Eprint.undip.ac.id (diakses 27 Juni 2014).

Tapotubun,A.M., E.E.E.M. Nanlohy, dan J.H. Louhenapessy. 2008. Efek wktu Pemansan Terhadap Mutu Presto Beberapa Jenis Ikan. Ichthyos 7(2): 65-70. Ichthyos, web.id/.../5-4\%2OH (diakses 27 Juni 2014). 